\title{
The Attitude of Indonesian Learners in Tertiary Level toward Spoken English and its Learning
}

Dr. Ammang Latifa, M.Hum

English Education Department of Graduate Program, Muhammadiyah University of Parepare, Indonesia

Corresponding Author: Dr. Ammang Latifa, M.Hum, E-mail: latifa_ammang@yahoo.com

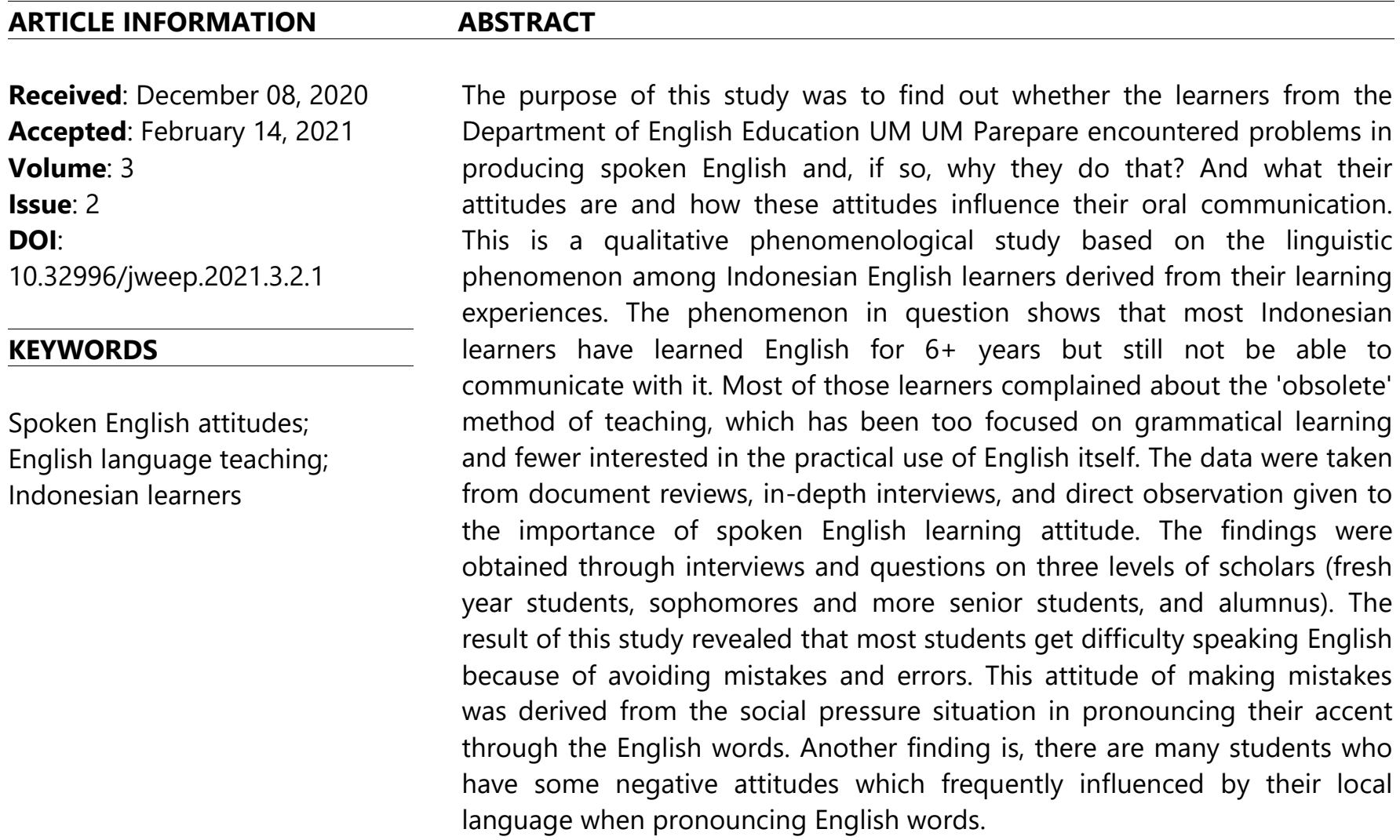

\section{Introduction}

English as a lingua franca had expanded its role and functions into non-native speakers' (EFL) life (Jenkins, 2020). To put it differently, the approval of English as a language also had grown largely globally (Majanen: 2008). The form of demand worldwide for succeeding a good demand for English among non-native speakers has been established. That leads to a situation where schools of many non-English speaking countries started to introduce English to their students from a young age. As for the current curriculum in Indonesia, English as a compulsory subject was introduced in junior high school. That means most Indonesian students started to learn English at their 12-13 age and were taught English for six years during their time in junior and senior high school.

Based on KTSP (current Indonesian curriculum) and Keputusan Dinas (Kepdis) No 541 Tahun 2018, 1 year period of studying English (2 semesters) is equivalent to 272 - 304 hours. That equivalent to 1632 - 1824 hours (1224 - 1368 hours, given that an hour classroom period in Indonesia is 45 minutes) of studying English in 6 years.

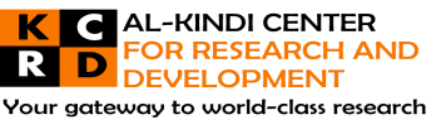

K C AL-KINDI CENTER Your gateway to world-class research

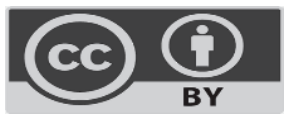

Published by Al-Kindi Center for Research and Development. Copyright (c) the author(s). This open access article is distributed under a Creative Commons Attribution (CC-BY) 4.0 license 
By using the US Foreign Service Institute guideline as a comparison to measure the time it will take to learn a language, where for Indonesian people, English can be categorized as a language with linguistic and/or cultural differences from Bahasa Indonesia, Indonesian people should be able to speak English fluently after studying the language for around 900 hours. But contradictory, it is a recognized fact that most high-school graduates are having difficulties when it comes to speaking English even after six years of studying the language (Akbari, 2015).

In principle, to be able to interact using English fluently, people must have comprehensive skills (Masuram, 2019). If an English speaker has limited competence, then he himself will have difficulty in choosing and using words to say (Rajitha \& Alamelu, 2020), or the speaker has a weakness in using sentences with neat grammar. All forms of difficulty may arise depending on the skill level of the speaker. It is undeniable that there is a side of language skills that can be monitored in someone when he is speaking English even though he still speaks English. while some studies have found that people who are not very skilled in English sometimes take advantage of their local accent. (Setter \& Jenkins, 2004 Skilled English speakers sometimes still use their local accent. as explained by Darwin and Munro (2009): The speaker whose skills are almost the same as the original speaker still has a local accent when speaking ."An example of a very good English skill, which is colored by its use with a very strong local accent, was carried out by the Prime Minister of the Netherlands, Mark Rutte, while speaking in English, was found in the Prime Minister of the Netherlands.

\section{Literature Review}

From time to time the role of English is increasingly important. This role appears in almost all aspects and spreads throughout the world, including in Indonesia. This condition gives the impact that the speakers outside the Englishspeaking country are more aware of wanting to speak English properly. However, it is still found that some nonnative speakers still use their local accent when speaking English. Local accents that are usually used by non-natives often hinder the clarity of meaning for the message conveyed. In addition, it is possible that the listener's attitude towards the speaker is less positive because of the (strong) non-native accent as stated in the previous reference that the impact of the influence of local accents cannot be said that this applies to all types of English speaking. The impact that may occur on English speakers who use local accents will be influenced by various variables. these variables are the variable of the listener's language competence, the type of accent, the thickness of the speaker's accent. While the thickness of the local accent sometimes also has the potential to cause positive behavior to the speaker.

For Indonesians who speak English the number is increasing.

This is oriented towards the impact of English intervention on Indonesian, causing many English-speaking speakers with local accents. We can find this English variant in Indonesia, for example in South Sulawesi.

The role of English is very large, including in the business world, causing many language researchers to conduct field observations to raise the theme of the influence of the Indonesian language on the mastery of English in Indonesia. This study aims to analyze attitudes that occur in Indonesian people when they speak English with an Indonesian accent.

This study investigated at the comparison of the behavior experienced by the speaker. Behavior in terms of talent, interest in English speakers who have a slight Indonesian accent and English speakers who have a thick Indonesian accent. This effort was carried out to develop the scale of the research theme because the results of previous research were that very young Indonesian speakers were intervened by English with Indonesian accents rather than English native speakers. Likewise, this study compares the attitudes of native Indonesian speakers and native English speakers towards English speakers with an Indonesian accent.

Paakki (2013) Exploring Finnish adult learners in English interaction. He found that most of them prefer to use a British accent when they speak English rather than using a Finnish accent. The next exploration is from Garrett (2010), who poses an issue in a question based on the fact that why do people tend to use other people's accents and dislike other's accents? Furthermore, Leppanen et al. (2009) Reinforce in their findings that most Finnish people, when speaking English are more likely to use a British accent than other accents. 
Garrett (2010) Suggests that the impact of positive behavior or negative behavior when speaking occurs because of the rules that apply to the language itself. Diversity of language habits often appears in its users. The standard language is oriented to the level of accuracy in the language by its users where the language applies. For example, the standard language is stored and studied in dictionaries, grammar books, and conveyed through the education system, and then reinforced through an award or praise in the form of language. For example, language accents have a significant impact on daily life interactions; as stated by Aharon (2020) that many immigrants in America with their accents actually bring problems to their living environment.

Ellemers et al. (2019) defined attitudes as a hypothetical construction put forward by several researchers describing events that cannot be observed but can be inferred from a report and an individual's attitude that the source of the attitude is Attitudes can be said to be part of heredity and the influence of the social environment. However, the experience can also shape people's attitudes due to environmental factors such as parents, media, teachers, and others (Garrett, 2010); for example, the attitude of the teacher giving instructions with his accent can directly affect the attitude of his students as Ahmadi (2013) said that avoiding speech errors is the goal in the target language. However, this attitude will have an unfavorable impact on the learner if this attitude is carried out to an extreme.

\section{Methodology}

This research was conducted in a qualitative method which based on post-positivism philosophy where truth accords to the nature of the object and will be used in searching the natural object condition (Sugiyono, 2012). As a qualitative research study, this research was presented in a descriptive narrative form. The final report will be a complete construction and description of the phenomena being studied from the sounds, feelings, actions, and meanings of the study participants. This goes beyond mere facts or surface appearance but stops being trivial and indifferent (Patton, 2002). To find the students' attitude data, the researcher explore their feelings, actions and meaning of study through their English Education, difficulties of speaking English, speaking Experiences, speaking Circumstances, and Accent attitudes. There were total 6 students as informants from UM Parepare being recorded. The researcher chose purposive sampling, considered by Welman and Kruger (1999) as the most important kind of non-probability sampling, to identify the primary participants

\section{Results and Discussion \\ a. Result}

This research was conducted in a qualitative method based on post-positivist philosophy where truth accords to the nature of the object and will be used in searching the natural object condition (Sugiyono, 2012). As a qualitative research study, this research was presented in a descriptive narrative form. The final report will be a complete construction and description of the phenomena being studied from the sounds, feelings, actions, and meanings of the study participants. This goes beyond mere facts or surface appearance but stops being trivial and indifferent (Patton, 2002).

To find the students' attitude data, the researcher explores their feelings, actions, and meaning of study through their English Education, difficulties of speaking English, speaking Experiences, speaking Circumstances, and Accent attitudes. There were a total of 6 students as informants from UM Parepare being recorded. The researcher chose purposive sampling, considered by Welman and Kruger (1999) as the most important kind of non-probability sampling, to identify the primary participants.

\section{b. Discussion}

When the participants were questioned about their view on accents and their current language teaching or English in general, they tend to forget about the cultural awareness and natural communication when it comes to learning a new language. Learning about accurate grammar, wide vocabulary, and clear pronunciation are undeniably important when learning English, but some words and phrases are not always culturally appropriate even though they make sense (Otzurk:2009). 
The purpose of this research project is to obtain information on whether English learners at UM Parepare have difficulties when communicating in English, and if so, what are the difficulties and what are the reasons behind these difficulties? According to the research report, UM Parepare students have difficulty speaking English orally. These difficulties are the emergence of feelings of awkwardness, lack of vocabulary, not being able to remember vocabulary, and so on.

Some of the reasons for the emergence of this problem are individual factors, accent factors, social factors, and acceptance of external input factors. Overall, respondents generally provide a variety of information. This is due to differences in attitudes in speaking English. Most of them think that speaking English is fun and the rest say it is not so fun.

This attitude seems to be interfered with by a positive attitude towards the teacher. A supportive and wise attitude towards wrongdoing can trigger students to be more active in speaking and improve their achievement in speaking English. Moyer's (2004), Anggayana et al., 2019)classification is useful when analyzing this research report. This is due to information from the whole; respondents said that most of the teaching factors and social factors a possible cause of their difficulties in speaking English. Instruction is the most important component in English speech activity. Many respondents said that they have a high enough fear of making mistakes because of weaknesses in social interactions in spoken language. (Cargile and Giles:1998).

There are several types of problems experienced in speaking English. This mainly deals with conditions of vocabulary recall, idea production, pronunciation, and listening skills. Another thing is the weakness of speaking skills because they are not supported by conversational habits (Fang:2016). Schumann's (1978) concept of culture shock applies to this investigation because speaking English who is not a native speaker has a similar process, namely that the teacher experiences culture shock. The process of speaking English is a process of culture shock, where the teacher first experiences something that may be pleasant, and then feelings of discomfort appear one after another, then followed by denial, realization, and acceptance.

However, In the group learning English as a foreign language, there is very little opportunity to be able to practice English confidence. This condition also arises with the assumption that the environment has its own stigma where the learner or teacher can adjust the conditions according to the circumstances. (Erzebet:2014). Therefore, English learners have a small chance to be more successful than mastering other languages. This impact can also lead to failure to develop confidence in English. (Rahman:2017).

This research has succeeded in raising some unique views and experiences related to English speaking skills. However, there are several issues that must be studied further, including how to direct students to be able to speak according to the actual situation. Another problem is the ability of the learner to distinguish the accent or voice of the interlocutor at least the speaker can say what he hears. he always raises the question of whether other people or the respondent himself can listen and break it down into certain things that can be trusted. Another possibility is whether the respondent can respond to all questions correctly and accurately. This is indicated by the existence of some unclear answers regarding attitudes towards accents.

Also, there may be more and varied input about barriers to speaking English. This can encourage the next research to interview students who specifically have many problems in speaking English practice and However, interviewing students who lack the courage to speak is also necessary. This effort will provide information for experts to be able to provide solutions for those who are not confident in speaking English. Furthermore, the data is going to be analyzed by grouping them into the factors that seemed to influence the verbal skills of informants in English. Using Moyer's classification (2004), they will be discussed in a separate section: individual factors, instruction factors, and social factors. However, many of these factors are interrelated, which makes classification somewhat problematic at certain times. The spoken English attitude is of particular interest in this study, which is why they will be discussed separately. 


\section{c. Analysis}

a) Individual factors

Several individual factors seem to influence the production of English speech. However, overall, individual factors, such as cognitive styles, are difficult to observe and analyze in this type of study, and that will require more studies to obtain more information about them. Firstly, personality seems to have an effect on speech production skills. Some informants stated that it was easier for them to speak English because they also spoke a lot in their native language, while people who think of themselves as shy at all times said that the condition is part of the main factor in communicating English orally. This is because English learners are very careful not to make mistakes when speaking. Another factor is the cognitive dimension which is also an important thing needed when interacting using spoken English. Many respondents stated that their failure was because they were not able to think optimally, especially remembering vocabulary and managing grammar when communicating using English. However, cognitive factors are not easily parsed and described in this study.

Some respondents recorded that their listening ability is much better than the ability to produce ideas. Habermas (1971), propositional sentences and performative sentences, can be used to measure the difference between these two abilities. A student, for example, provides that information when he or she is speaking. Then he has designed a complete and well-ordered sentence. However, when he produces it with speech, then something different happens what he has prepared in his mind.

Some respondents also provided information that they had problems distinguishing some English sounds or words. In addition, they also added that another difficulty they experienced was that their pronunciation was problematic. Those kinds of the situation had been causing frustration for the learners thus prevented them from speaking. Researchers think this will be explored in another study in the future. He explained, from the results of data analysis on respondents, it was found that listening ability is a serious factor to be successful in communicating English. There is also information that a lot of anxiety factors prevent them from speaking. They tend to avoid attempting to perform in the target language (Rahman:2017).

\section{a) Instruction factors}

Instructions greatly affect the English language skills of the informant. First, all informants have received the same teacher-oriented English education that concentrates on literary, grammatical, and translation skills, and very few practiced verbal skills. They seem dissatisfied with their education and experience that lack speaking practice. It becomes the main factor causing success or failure in English. In addition, their knowledge of their speech is very minimal, so that it affects their verbal communication skills. The problem seemed to be not being accustomed to the production of speech, thinking of the idea of conversation.

However, for most students, their current English learning group has succeeded in increasing their confidence in English speaking skills and their readiness to speak. Instrumental motivation is the key to this development (Anwar et al., 2020). The student who has adopted the idea of success in conveying messages or communication as the essential factor in communicating English. It should be more relaxed when doing English speaking, and it should not worry about making mistakes (Latifa and Nur, 2019). But there are also some students who still seem to feel insecure about their ability to speak English. Literary skills appear to be more developed than speaking skills; for example, an informant reports that he writes texts in English for his work but cannot speak much English. The present researcher observed that many students from the UM Parepare Department of English Education had developed English textual skills, but many can or do not want to speak much English.

\section{b) Social factors}

The social factor is one of the basic factors for the respondent to communicate in English: support from the environment is important. Some respondents said that it helps to build motivation. After all, the certain environment makes it difficult for language learners to take a keen interest in the process of learning English (Otzurk: 2009).

That might have something to do with social factors and feedback. Therefore, social pressure can be the main driving force for the speaker to say the words. Wise people say intelligence is the key. that is highly valued in today's society, 
and as such, it was not surprising that non-native English speakers are concerned with sounding foolish. Therefore, social pressure can be the main driving force for the speaker to say the words. Wise people say intelligence is the key. an Indonesian accent on campus or when someone had to meet the requirements also concluded that the Indonesian accent did not have the type of prestige like the British accent, for example. There are a number of respondents who seem to have concerns about other people's speech about their ability to speak English. As one informant said, it seems that people don't have many opportunities to practice speaking English, but when they suddenly have to speak English, it might be quite confusing.

Social views give the impression that speaking English is very difficult for respondents to do. They firmly believe that proficiency and accent in English plays an important role in reflecting a reliable and reliable work (Woydack \& Lockwood, 2019). Another interesting matter was that in the informants' environment, even beginner's English language skills also have some social prestige. The results are relevant and go along the same line with the research conducted by Cargile and Gilles (1998); Chiba, Matsura, and Yamamoto (2007); Erzebet (2014); and Fang (2016). Even the most basic conversations conducted in English will generate awe and admiration, among others. However, this can also separate one from the group, and therefore create peer pressure.

\section{c) Accent Attitudes}

Accent attitude is also a source of problems in the production of English speech (park et al., 2017); (Nugroho, 2020). The favoritism of native-sounded varieties, especially $\mathrm{BrE}$, and in some cases $\mathrm{AmE}$, and once again the strict attitude towards Indonesian English accents seems to create unrealistic goals for learning English. Most of the respondents do not provide information transparently if actually speaking English is very difficult to do because they were worried about their accent. However, many of them have a firm attitude towards accent they have. They want to communicate in English fluently and use a pleasant accent like a native speaker, and it has been recorded that they really have difficulty in pronunciation.

In Leppänen et al. (2009), accent attitudes were related to education: people with higher education, for example, admire the native accent the most (Leppänen et al., 2009). According to the informants, there is strong favoritism towards British accents in their late education, which again is very likely to have influenced at their language performance because many of them preferred British accents. Similar to Leppänen et al. (2009), most informants reported admiration for British accents, for example, but not as much as Indonesian accents. However, a couple of informants also liked Indonesian accents, and Some are amazed at people who can speak English. Many informants, once again, said that the Indonesian accent was stupid, careless, etc. Teachers often preferred accents that sounded native, but according to informants, do not openly say anything negative about Indonesian English accents. Then again, some teachers preferred accents that sounded native but had not spoken it themselves. This type of favoritism might make someone like accents more than others without realizing it, but it might appear a shock if the teacher also cannot produce the accents either (Chiba et al., 2007). Many said that the philosophy of their previous education was "if you can't pronounce correctly, it's better to stay quiet."

It's better if it will sound more reliable and credible, many felt that having an Indonesian the English accent does not have a positive impact. Several respondents said that many politicians don't do much work to get a British accent, for example, when in fact, it is very difficult. So, it seems that many informants had the wrong response about speaking English is very difficult with an accent like a native, which again may be a reason for pressure. In addition, many people seem to think that Indonesian, in general, is very good in English, and even some informants mention this. it also allows the encouragement to learn to speak English, especially if we have very high aspirations.

Information from a number of respondents said that native English speakers are interesting to hear compared to English with Indonesian speakers' accents which have less good quality. This attitude sometimes appears unconsciously, which may serve the purpose of explaining things about contradicting accent sounds. This may be because a number of respondents lack a high level of nationalism and perhaps also because of their own interest in certain accents. Garrett (2010) and Fielding and Evererd (1980) observed the strong prejudices which can be created 
based on accents. It also seemed to be carried out to this research because distinguishing between a near-native pronunciation and good language skills as a whole seems rather difficult.

In addition, In general, respondents agree that many of their teachers waste time just thinking that their students must master the material that has been taught during the learning process. They hope that their students will be able to match the achievements of their teachers. Furthermore, they also want to be recognized as having succeeded as teachers. Teachers should be aware that the spoken language they teach their students in their subjects is much different from the spoken English that exists outside the school environment.

Otzurk (2009) states that learning English in schools that have been determined by the curriculum is very different from everyday conversations, which are spontaneous, sometimes irregular because they do not go through a planning process. The impact of this spontaneous spoken language is that grammatical errors often occur, the wrong choice of vocabulary because sometimes they get intervention from their mother tongue. However, if the learners think that they can do spoken English communication when they do the writing task, then that will be a big problem.

This happens because their campus environment allows this negative behavior towards students who are learning to speak English. Some students who were taken as respondents admitted that they had received lessons from their homes on how to learn to speak English well.

English teaching nowadays is weight, focus a lot on grammar teaching, and force the students to memorize many vocabularies. It is not something that can be considered ineffective but could be misleading, according to informants. Most students were taught how they could have success in a test, but then that is it. Most of the learners are not conversationally fluent. That being said, the majority of the participants still think that vocabulary memorizing is an important matter to learn English, but the majority of them are also aware of the fact that specific vocabulary can be acquired over time. However, as language learners, they think that they should be able to elicit and describe to explain. They aim to be able to describe or paraphrase English as language content using English as their target language itself without needing to translate using their native language.

\section{Conclusion}

This research project has a goal, namely to find out and analyze through behavioral data of students majoring in English at UM Parepere, do they face problems when they communicate orally in English? If so, why did that happen? And what kind of behavior do they have? Then how the forms of student behavior intervene to the teacher when speaking English. A number of data are taken from information from interviews with respondents, which are very interesting in their discussion, as we have described in the findings and discussion section. From the analysis of the data we obtained, there were several issues that were conveyed by the respondents less long ago in previous studies. Information from respondents also raises many questions that need to be studied further by future research. The conclusion from the overall analysis of information from respondents is that speaking English is not easy; it requires patience and perseverance. We can say that this is a very big challenge for English-speaking practitioners and teachers. In terms of giving punishment to students' mistakes, teachers should be wiser in implementing the punishment.

There are two factors that greatly contribute to the success and failure of English learners, namely social factors and learning factors in the classroom. In addition, the supporting factor, in this case, is the problem of the learner's accent when speaking English. From the respondent's data, it has been found that many interesting things about accents are also sometimes contradictory. In this information, we have difficulty saying that the accent factor is a source of inhibition for English learners to want to communicate in English.

However, the fact that the data shows that most of the respondents (English students) have a negative attitude towards their local accent when they are learning to communicate in English. Native speaker norms have a solid status as appropriate models for English production, which is likely to be a source of pressure, especially if they are liked but not produced successfully. 
The rules of native speakers can be used as a strong foundation and standard model in terms of speaking English. The standard rules of native speakers are certain to put pressure on the learner. The rule is certainly loved but very difficult to enforce.

Many English speakers have a clear understanding of English in general, including the use of different accents. However, these speakers are more likely to use their local accent when communicating in English.

\section{References}

[1] Akbari, Z. (2015). Current challenges in teaching/learning English for EFL learners: The case of junior high school and high school. Sciencedirect Journal. Retrieved from https://www.sciencedirect.com/science/article/pii/S1877042815045358

[2] Ahmadi, M.R. (2011). Why is Pronunciation So Difficult to Learn?. http://www.ccsenet.org/

[3] Anwar, M., Yusri and Hasmawati. (2020). Improving Student's Speaking Performance and Self-Confidence Using Mind Mapping Model in Foreign Language Learning, Asian EFL Journal. http://www.asian-efl-journal.com

[4] Anggayana, Budasi and Kusuma. (2019). Social Dialectology Study of Phonology in Knowing English Student Speaking Ability. Asian EFL Journal. http://www.asian-efl-journal.com

[5] Aharon, A., B. (2020) Proud or Problem: When Your Accent Becomes a Self-Esteem Problem. Great Speeach.com. retrieved from . https://greatspeech.com/proud-or-problem-when-your-accent-becomes-a-self-esteem-problem/

[6] Cargile, Aaron C., and Howard Giles. (1998). Language attitudes toward varieties of English: An American-Japanese context. Journal of Applied Communication Research, Retrieved from https://www.tandfonline.com/doi/abs/10.1080/00909889809365511

[7] Chiba, R., Matsuura, H. \& Yamamoto, A. (2007). Japanese attitudes toward English accents. World Englishes: Wiley Online Library. Retrieved from https://onlinelibrary.wiley.com/doi/epdf/10.1111/j.1467-971X.1995.tb00341.x

[8] Derwing and Munro (2009). Putting accent in its place: Rethinking obstacles to communication. Language Teaching: Survey studies. Retrieved from https://www.cambridge.org/core/journals/language-teaching/article/abs/putting-accent-in-its-place-rethinking-obstacles-tocommunication/11D7A6BB87C915E074F50DE01FB7995F

[9] Ellemers, N., Jojanneke van der Toorn, J.van Der., Paunov, Y. (2019). The Psychology of Morality: A Review and Analysis of Empirical Studies Published From 1940 Through 2017. Sage Journals. Retrieved from https://journals.sagepub.com/doi/full/10.1177/1088868318811759

[10] Erzsébet, B. (2014). Language attitudes towards English accent varieties: Hungarian secondary school students' labeling, evaluating and commenting on foreign accented Englishes. Semantic Scholar. Retrieved from. https://www.semanticscholar.org/paper/Language-attitudestowards-English-accent-Hungarian-Erzs\%C3\%A9bet/bdd429faa2f6210ad91faf6bb8b4dbfeff7808c2

[11] Fang, Fan. (2016). Investigating Attitudes towards English Accents from an ELF Framework. Research gate. Retrieved from. https://www.researchgate.net/publication/316614087 An Investigation of Attitudes Towards English Accents A Case Study of a University in China

[12] Fielding, G. \& Evererd, C. (1980). 'The Influence of Patients' Speech upon Doctors: the Diagnostic Interview' in St. Clair, R. \& Giles, H. (Eds.) The Social and Psychological Contexts of Language. Hillsdale, NJ: Erlbaum. 51- 72.

[13] Garret. (2010). Key Topics in Sociolinguistics: Attitude to Language. New York. Cambridge University Press

[14] Habermas, J. (1971). Vorbereitende Bemerkungen zu einer Theorie der kommunikativen Kompetenz'. In Habermas \& Luhmann (Eds.), Theorie der Gesellschaft oder Sozialtechnologie. Frankfurt: Suhrkampf. 101-141.

[15] Horwitz, E.K. (1986). Preliminary evidence for the reliability and validity of a foreign language anxiety scale. TESOL Quarterly Journal. 20. 559-320.

[16] Jenkins, J. (2020). English as a Lingua Franca from the classroom to the classroom. Research Gate. Retrieved from https://www.researchgate.net/publication/262243160_English_as_a_Lingua_Franca_from_the_classroom_to_the_classroom

[17] Latifa, A \& Nur, R. (2019). Communication Strategies of Indonesian EFL Learners in Speaking English. Asia EFL Journal. Retrieved from https://www.elejournals.com/asian-efl-journal/volume-23-issue-6-2/

[18] Leppänen et al. (2009). Kansallinen kyselytutkimus englannin kielestä Suomessa: käyttö, merkitys ja asenteet. University of Jyväskylä.

[19] Leppänen, Sirpa, Anne Pitkänen-Huhta, Tarja Nikula, Samu Kytölä, Timo Törmäkangas, Kari Nissinen, Leila Kääntä, Tiina Virkkula, Mikko Laitinen, Päivi Pahta, Heidi Koskela, Salla Lähdesmäki \& Henna Jousmäki. 2009a. Kansallinen kyselytutkimus englannin kielestä Suomessa: Käyttö, merkitys ja asenteet [National Survey on the English Language in Finland: Uses, Meanings and Attitudes]. Jyväskylä Studies in Humanities 132.

[20] Nugroho, A.,S., Suzila, T,I., T.S, Yusnarso, R., F., Akmal. (2020). Comparative Study Of English Vowel Sounds Among Solo And Surabaya EFL Students. International Journal of Scientific \& Technology Research. Retrieved from http://www.ijstr.org/paper-references.php?ref=IJSTR0120-29317

[21] Majanen. (2008). English as a Lingua Franca: Teachers' Discourses on Accent and Identity. MA Thesis Department of English University of Helsinki.

[22] Masuram, J \& Sripada P., N. (2019). 9th World Engineering Education Forum 2019, WEEF 2019. Sciencedirect Journal. Retrieved from https://www.sciencedirect.com/science/article/pii/S1877050920313326

[23] Moyer, A. (2004). Age, Accent, and Experience in Second Language Acquisition: An Integrated Approach to Critical Period Inquiry. Clevedon, GBR: Multilingual Matters Limited.

[24] Öztürk,G. (2009). Foreign Language Speaking Anxiety and Learner Motivation: A Case Study at a Turkish State University (Unpublished master's thesis). METU, Ankara.

[25] Park, E., Tsurutani, K. C., \& Harte, W., Minami, M. (2017). International students' accented English—Communication difficulties and developed strategies. Tandfonline Journal. Retrieved from https://www.tandfonline.com/doi/full/10.1080/2331186X.2017.1314651

[26] Patton, M. (2002). Qualitative research \& evaluation methods (3rd ed.). Thousand Oaks, CA: Sage I 
[27] Rahman, A, W. (2017). How Good EFL Learners Decrease Their Foreign Language Anxiety: A Solution for the EFL Students with High Anxiousness. Ethical Lingua: Journal of Language Teaching and Literature, 4(2), 127-138. https://doi.org/10.30605/ethicallingua.v4i2.625

[28] Rajitha K \& C.Alamelu. (2020). A Study of Factors Affecting and Causing Speaking Anxiety. Sciencedirect Journal. Retrieved from https://www.sciencedirect.com/science/article/pii/S1877050920314848

[29] Setter \& Jenkins. (2004). State-of-the-Art Review Article. Research gate. Retrieve from. https://www.researchgate.net/publication/231950373_State-of-the-Art_Review_Article

[30] Schumann, J.H. 1978. The Pidginization Process. Rowley, Massachusetts: Newbury house publishers.

[31] Sugiyono, (2012). Memahami Penelitian Kualitatif. Alfabeta, Bandung

[32] Welman, J. C., \& Kruger, S. J. (1999). Research methodology for the business and administrative sciences. Johannesburg, South Africa: International Thompson

[33] Woydack. J, \& Lockwood, J. (2019). Affordances for language learning in a call centre. Science direct Journal, Retrieved from https://doi.org/10.1016/j.esp.2020.04.005. https://www.sciencedirect.com/science/article/abs/pii/S0889490620300338?dgcid=rss_sd_all 